\title{
CELL CYCLE ANALYSIS AND PROPERTIES OF TWO SUB-POPULATIONS IN PHA RESPONDING LYMPHOCYTES
}

\author{
A Comparison of 21-Trisomic and Normal Cells \\ Kunikazu KISHI \\ Department of Cytogenetics, Medical Research Institute, \\ Tokyo Medical and Dental University, Yushima, Tokyo 113
}

\begin{abstract}
Summary In order to investigate the properties of the trisomic cells in patients with Down's syndrome, comparisons of the cell cycle, durations of component phases and chromosomal sensitivities were performed both in trisomic and normal lymphocyte cultures, using ${ }^{3} \mathrm{H}$-thymidine autoradiography. In the present experiments, the presence of the two cell sub-populations was found in trisomic cells as well as in normal cells.

The durations of the $\mathrm{G}_{2}+\mathrm{M}$ and $\mathrm{S}$ phases were similar in both subpopulations, 3.9 and $8.1 \mathrm{hr}$ for trisomic cells and 4.6 and $7.9 \mathrm{hr}$ for normal cells, respectively. For the longer cell cycle sub-population, the duration of the total cell cycle and the $G_{1}$ phase were 23.1 and $11.1 \mathrm{hr}$ for the trisomic cells and 20.4 and $7.9 \mathrm{hr}$ for the normal controls. For the shorter cell cycle subpopulation, those were 13.2 and $1.3 \mathrm{hr}$ for the trisomic cells and 12.7 and 0.8 hr for the normal controls, respectively.

Chromosomal sensitivities to incorporated ${ }^{3} \mathrm{H}-\mathrm{TdR}$ were similar in two sub-populations within a group, but significantly higher chromosome aberration yields were observed in the trisomic cells.
\end{abstract}

\section{INTRODUCTION}

Trisomic cells from patients with Down's syndrome have some different properties as compared with normal diploid cells from healthy persons. For instance, the hyperblastic responses of trisomic cells have been shown in mixed lymphocyte cultures of normal persons and patients with Down's syndrome (Sasaki and Obara, 1969) and in cultures stimulated by low concentrations of phytohemagglutinin (PHA) (Hayakawa et al., 1968; Matte et al., 1969). The chromosomes of patients with this syndrome are more susceptible to damages by ionizing radiations (Sasaki and Tonomura, 1969), certain chemicals (O'Brien et al., 1971; Schuler et al., 1972) and viruses (Higurashi et al., 1973, 1976).

More recently, the experimental results indicated that the duration of the $G_{2}$ phase of trisomic cells is longer than that of normal cells (Kukharenko et al., 1974; Paton et al., 1974) and the cell growth rates are very slow in trisomic conditions (Segal 
and McCoy, 1973). These properties in the trisomic cells have been discussed in relation to some physiological abnormalities in Down's syndrome such as growth retardation and increased susceptibility to viruses or leukemia (Kukharenko et al., 1974; Paton et al., 1974). For understanding these phenotypical effects of chromosomal disbalance on the cellular level, it is necessary to clarify the differences in the properties between trisomic and normal cells in more detail.

In the course of investigations of the stage sensitivity of trisomic cells to chemical mutagens, the author observed the presence of two sub-populations in PHA-stimulated lymphocytes in patients with Down's syndrome. The present study deals with measurements and comparison of the cell cycle time and duration of the component phases in two sub-populations between trisomic and normal cells. In addition, the chromosomal sensitivities of trisomic and normal cells to incorporated tritiumthymidine $\left({ }^{3} \mathrm{H}-\mathrm{TdR}\right)$ were compared in each sub-population.

\section{MATERIALS AND METHODS}

Four patients with Down's syndrome ( 2 males and 2 females) and 4 normal persons ( 2 males and 2 females) were selected for the present experiment. All the patients with Down's syndrome were confirmed to be $47, \mathrm{XX}$ or $\mathrm{XY},+21$. In the control group three had apparently normal karyotypes and one was a translocation carrier with $45, \mathrm{XX}, \mathrm{t}(21 \mathrm{q} 21 \mathrm{q})$.

\section{Cell culture and autoradiography}

Whole blood cultures were set up as follows: One part of the heparinized blood was introduced into 19 parts of pre-warmed medium, consisting of medium NCTC109 (Gibco), fetal calf serum (Gibco) and reconstituted PHA-M (Gibco) in the volume ratio of $4: 1: 0.2$, and $5-\mathrm{ml}$ aliquotes were transferred into 9 to 11 sterile plastic culture tubes (Falcon, $16 \times 125 \mathrm{~mm}$ ) and then incubated at $37^{\circ} \mathrm{C}$. Each experiment was conducted by the use of a set of two cultures, one from the patient and the other from the normal person.

Before fixation, a 30-min incubation in medium TC-199 containing ${ }^{3} \mathrm{H}-\mathrm{TdR}$ (1 $\mu \mathrm{Ci} / \mathrm{ml}$, specific activity $5.0 \mathrm{Ci} / \mathrm{mm}$, Radiochemical Centre, Amersham) was carried out periodically according to the experimental schedule. After the treatment, the medium containing ${ }^{3} \mathrm{H}$-TdR was removed, and cells were re-incubated at $37^{\circ} \mathrm{C}$ in a pre-warmed medium, consisting of medium NCTC-109, fetal calf serum and $50 \mu \mathrm{M}$ 'cold' TdR until fixation time. Two hours before fixation, colchicine was added to each culture tube at a final concentration of $1 \mu \mathrm{g} / \mathrm{ml}$.

Chromosome preparations were made by means of the ordinary air-drying technique after hypotonic treatment and acetic acid-methanol fixation. After linsing in cold 5\% trichloroacetic acid (E. Merck) for $30 \mathrm{~min}$ and washed for $3 \mathrm{hr}$ in running water, the slides were covered with Kodak NTB-3 nuclear track emulsion, exposed 
for a week at $4^{\circ} \mathrm{C}$ and developed for $3 \mathrm{~min}$ at $10^{\circ} \mathrm{C}$ in full strength of Kodak developer Dektol.

Cell cycle analysis

In order to measure the metaphase labelling indices (MLI), 200 to 400 metaphases were scored in each preparation. The ratios of the first (i.e. both chromatids were labelled), second (i.e. only one chromatid was labelled in most of chromosomes) and third post-labelling mitoses (i.e. one chromatid was labelled in nearly half of chromosomes) were estimated based on a count of 50 to 100 cells and then multiplying each ratio by the corresponding MLI, their frequencies were plotted for each labelling pattern.

Measurements of the cell cycle and phase durations were made according to the method of Paton et al. (1974). The details will be described in the Result section.

\section{Evaluation of chromosome aberrations}

Since it is expected that the late replicating $X$ chromosome in female cells shows higher chromosome aberrations when treated with ${ }^{3} \mathrm{H}-\mathrm{TdR}$ in late $\mathrm{S}$ phase (Okey, 1967), only male samples were selected for this study. Preparations representative of each sub-population were selected and well-spread metaphases with one chromatid being densely labelled were chosen. After removal of grains by potassium ferricyanide solution and photographic fixer, chromosome analyses were made in 50 cells for each sample. Chromosome aberrations were classified into the following 10 categories: Single chromatid gaps, iso-chromatid gaps, single chromatid breaks, isochromatid breaks, chromatid exchanges, dicentrics, rings, abnormal monocentrics, translocations and acentric fragments.

\section{RESULTS}

\section{2-hr cultures}

In 72-hr cultures, a pair of cultures was treated with a $30-\mathrm{min}$ pulse of ${ }^{3} \mathrm{H}-\mathrm{TdR}$ at 35 to $38 \mathrm{hr}$ after culture initiation and duplicated samles were then treated at 3- or 4-hr interval over the next $31 \mathrm{hr}$. The results are presented in Fig. 1, in which three curves correspond to the MLI of the first, second and third post-labelling mitoses. In the four experiments, the MLI curves of the first post-labelling mitosis were similar in the trisomic and control cells, respectively. Therefore, the data of each group were combined and the MLI for each time period were then plotted as a single curve (Fig. 2). Following the pooled MLI curve, each curve of the first post-labelling mitosis was retouched in order to fix position of the peak point $\left(\mathbf{P}_{1}\right)$ in each curve.

The MLI patterns of the second post-labelling mitosis showed a bimodal curve in each experiment (Fig. 1). These figures indicate the presence of two sub-populations of cells in PHA-stimulated leukocyte cultures, distinguished by different cell cycle time. In this study, the author assumed that the curves were a combination of 

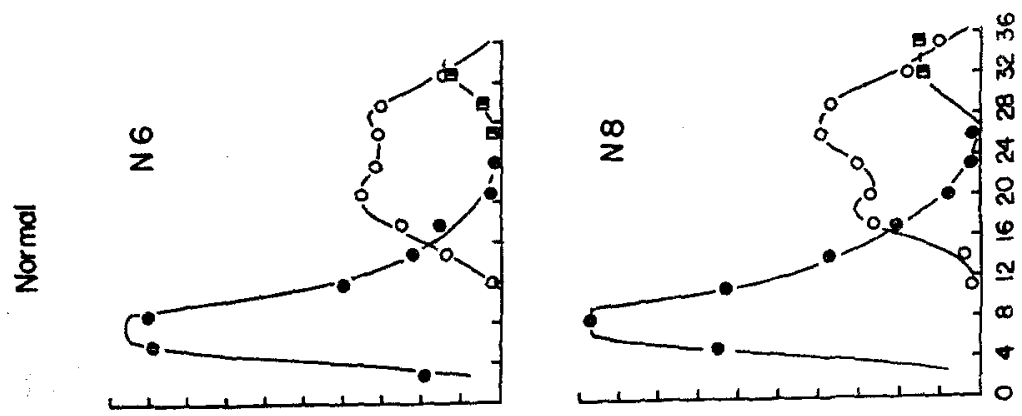

$\frac{1}{\overrightarrow{0}} \tilde{\Xi}$

采兄是

뭉
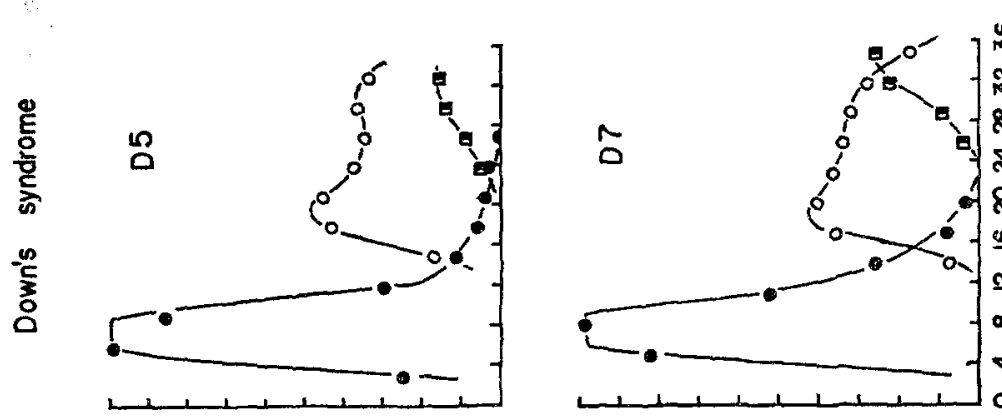

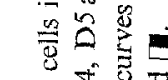

E

न 20

里邑点

㟧

西 0

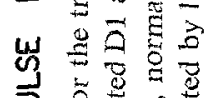

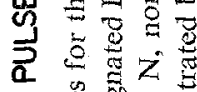
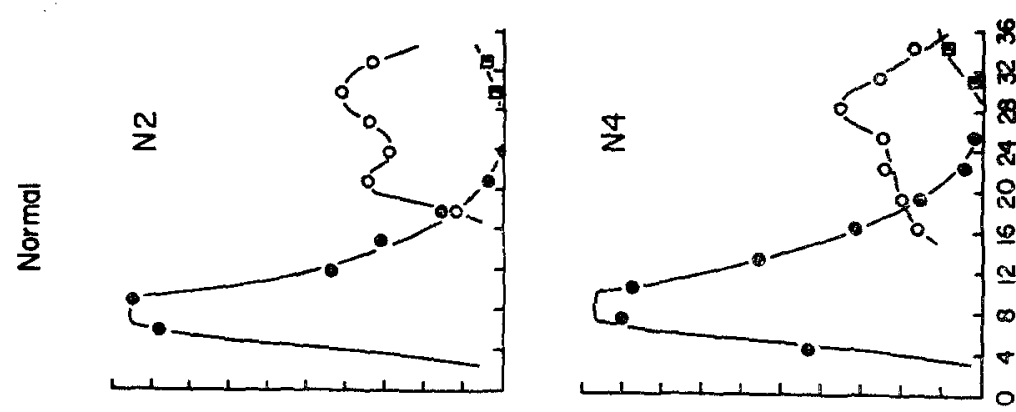

w

$\mp 2 \cdot 0$

$\propto$ 过导

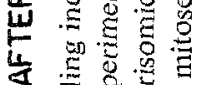

世苛周

$\sum \frac{5}{5} 0$

要要

跣

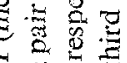

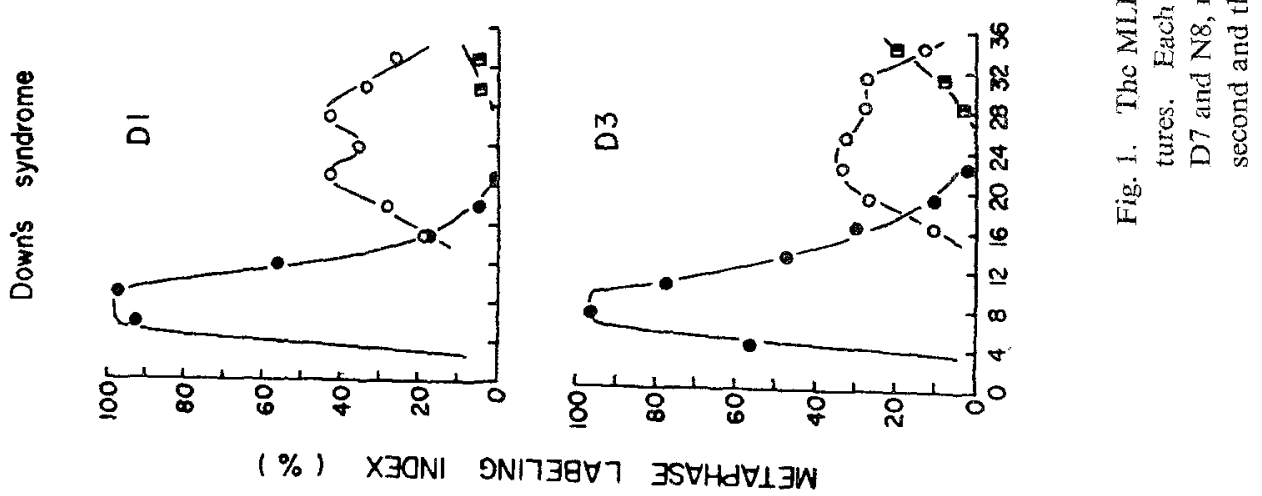




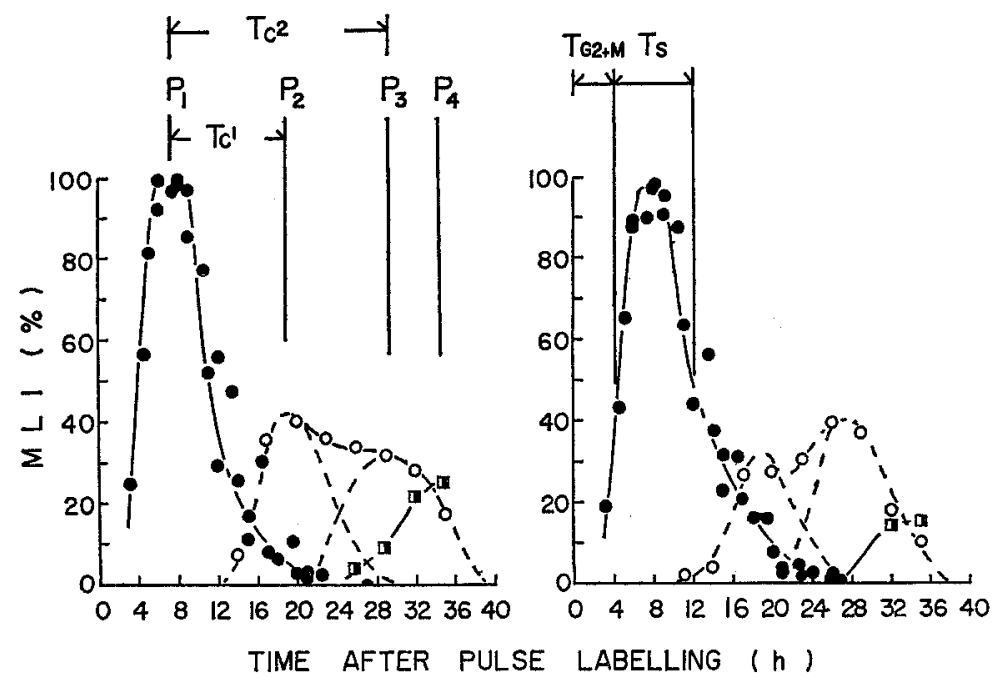

Fig. 2. Illustrations of the cell cycle analyses in 72-hr cultures. Left, trisomic cells; right, normal controls. The peak points are disignated $P_{1}, P_{2}, P_{3}$ and $P_{4}$ for the first, two second and the third post-labelling mitoses, respectively. $T_{C^{1}}$ and $T_{C}{ }^{2}$ are total cell cycle times of the shorter and longer cell cycle sub-populations. $\mathrm{T}_{\mathrm{G} 2+\mathrm{M}}$ is the duration of the $G_{2}$ plus $M$ phases and $T_{S}$ is the duration of DNA synthetic phase.

two symmetrical distribution curves as illustrated by a dotted line in Fig. 2. However, there were considerable differences both in the MLI and in the time periods of the second and third peak points $\left(\mathrm{P}_{2}\right.$ and $\left.\mathrm{P}_{3}\right)$ among the four experiments in each group. Therefore, the shorter and longer cell cycle times $\left(T_{C}{ }^{1}\right.$ and $\left.T_{C}{ }^{2}\right)$ were estimated from each experiment by measuring the intervals from $P_{2}$ to $P_{1}$ and $P_{3}$ to $P_{1}$.

The times of component phases were measured from the MLI curves as follows: The times of the sum of $G_{2}$ and $M$ phases $\left(T_{G_{2}+M}\right)$ was measured from halfway down left-side slope) the MLI of the initial peak $P_{1}$ to zero time. The time of the $S$ phase $\left(T_{S}\right)$ was estimated as the interval between two points of half the MLI of the peak $P_{1}$ on ascending and descending slopes. The durations of the $G_{1}$ phase in the shorter and longer cell cycle sub-populations $\left(\mathrm{T}_{\mathrm{G}_{1}}{ }^{1}\right.$ and $\left.\mathrm{T}_{\mathrm{G}_{1}}{ }^{2}\right)$ were determined by deducing the sum of $T_{S}$ and $T_{\mathrm{G}_{2}+\mathrm{M}}$ from $T_{\mathrm{C}}{ }^{1}$ and $T_{\mathrm{C}}{ }^{2}$, respectively, assuming that $T_{\mathrm{S}}$ and $T_{\mathrm{G}_{2}+\mathrm{M}}$ were identical for both sub-populations.

The results of measurements of the cell cycle time and the duration of component phases for two sub-populations in the trisomic and normal cells are listed in Table 1. The mean durations of $T_{S}$ were very similar in both groups but $T_{G_{2}+M}$ was somewhat shorter in the trisomic cells than in the normal controls. In the shorter cell cycle sub-population, the mean time of the total cell cycle was not differed both in the trisomic and normal cells. On the other hand, the mean cell cycle time for the longer cell cycle sub-population was longer in the trisomic cells than in the controls. Among 
Table 1. Mean durations of cell cycle and component phase of the trisomic and normal cells in 72-hr cultures.

\begin{tabular}{lcccccrr}
\hline \multirow{2}{*}{ Types of cells } & \multicolumn{2}{c}{ Cell cycle times (hr) } & & \multicolumn{3}{c}{ Durations of component phases (hr) } \\
\cline { 2 - 3 } \cline { 5 - 7 } & $\mathrm{T}_{\mathrm{C}}{ }^{1}$ & $\mathrm{~T}_{\mathrm{C}}{ }^{2}$ & & $\mathrm{~T}_{\mathrm{G}_{2} \mathrm{M}}$ & $\mathrm{T}_{\mathrm{S}}$ & $\mathrm{T}_{\mathrm{G}_{1}{ }^{1}}$ & $\mathrm{~T}_{\mathrm{G}_{1}{ }^{2}}$ \\
\hline Trisomic & $13.2 \pm 1.1$ & $23.1 \pm 0.7$ & & $3.9 \pm 0.1$ & $8.1 \pm 0.5$ & $1.3 \pm 0.5$ & $11.1 \pm 1.7$ \\
Normal & $12.7 \pm 0.6$ & $20.4 \pm 0.4$ & & $4.6 \pm 0.2$ & $7.9 \pm 0.4$ & $0.8 \pm 0.5$ & $7.9 \pm 0.8$ \\
\hline
\end{tabular}

Table 2. Ratios of the areas under the 72-hr MLI curves of the first and second post-labelling mitoses in the trisomic and normal controls. P1 indicates the area under the MLI curve in the first post-labelling mitosis. $\mathrm{P} 2$ and $\mathrm{P} 3$ indicate the areas under the MLI curves in the shorter and longer sub-populations, respectively.

\begin{tabular}{cccccc}
\hline Individuals & $\begin{array}{c}(\mathrm{P} 2+\mathrm{P} 3 / \mathrm{P} 1) \\
(\%)\end{array}$ & $\mathrm{P} 2 / \mathrm{P} 3$ & Individuals & $\begin{array}{c}(\mathrm{P} 2+\mathrm{P} 3 / \mathrm{P} 1) \\
(\%)\end{array}$ & $\mathrm{P} 2 / \mathrm{P} 3$ \\
\hline D1 & 79.3 & $\mathbf{0 . 8 5}$ & $\mathrm{N} 2$ & 71.9 & 0.55 \\
D3 & 53.8 & 2.92 & $\mathrm{~N} 4$ & 51.8 & 0.54 \\
D5 & 99.4 & 1.13 & $\mathrm{~N} 6$ & 70.7 & 1.32 \\
D7 & 85.3 & 0.99 & $\mathrm{~N} 8$ & 66.3 & 0.67 \\
\hline Av. & 79.5 & $\mathbf{1 . 4 7}$ & $\mathrm{Av}$ & 65.2 & $\mathbf{0 . 7 7}$ \\
\hline
\end{tabular}

the durations of component phases, the $\mathrm{T}_{\mathrm{G}_{1}}{ }^{2}$ in the trisomic cells was longer by about $3 \mathrm{hr}$ than that in the controls $(\mathrm{p}<0.05)$.

The proportion of cells having entered mitosis more than twice at $72 \mathrm{hr}$ after PHA stimulation were determined by comparing the areas under the first and the second post-labelling MLI curves. The proportions of lymphocytes which passed mitosis more than twice at $72 \mathrm{hr}$ were varied from experiment to experiment, but in each pair of the experiments, the ratio in the trisomic cells exceeded that in the controls (Table 2).

Although there were considerable variations in the amount of the two subpopulations between experiments, difference has been found between the trisomic and normal cells. In the trisomic cells, the proportion of the shorter cell cycle subpopulation was exceeded or almost equal to that of the longer cell cycle sub-population. On the other hand, in the normal cells, the proportion of the shorter cell cycle sub-population was never greater than that of the longer one except for one experiment in which the amounts of two sub-populations are nearly equal (Table 2).

The presence of the third post-labelling mitoses were detected in the culture series labelled at more than $28 \mathrm{hr}$ before fixation.

\section{8-hr cultures}

In 48-hr cultures, 30-min pulse-labellings were made at various times after culture initiation from 24 to $45 \mathrm{hr}$ with 3- or 4-hr intervals. The MLI patterns are presented in Fig. 3, in which a single curve was drawn for each group based on the two experiments. The durations of the $\mathrm{G}_{2}$ plus $M$ phases $\left(\mathrm{T}_{\mathrm{C}_{2}+\mathrm{M}}\right)$ and the $S$ phase $\left(\mathrm{T}_{\mathrm{S}}\right)$ are 


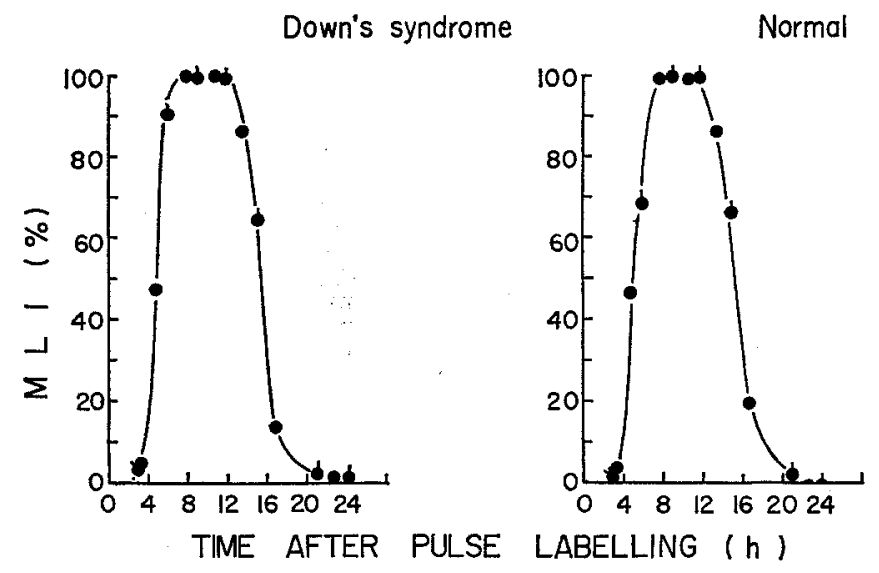

Fig. 3. Mean MLI curves of the trisomic and normal cells in 48-hr cultures.

Table 3. Mean durations of $\mathrm{T}_{\mathrm{G}_{2+} \mathrm{M}}$ and $\mathrm{T}_{\mathrm{S}}$ of the trisomic and normal cells in $48-\mathrm{hr}$ cultures.

\begin{tabular}{ccc}
\hline \multirow{2}{*}{ Type of cells } & \multicolumn{2}{c}{ Durations (hr) } \\
\cline { 2 - 3 } & $\mathrm{T}_{\mathrm{G}_{2}+\mathrm{M}}$ & $\mathrm{T}_{\mathrm{S}}$ \\
\hline Trisomic & 4.8 & 10.6 \\
Normal & 5.0 & 10.4 \\
\hline
\end{tabular}

listed in Table 3. Similar durations in both phases were obtained for the trisomic and normal cells, but they were somewhat longer than the durations measured from 72hr cultures. The second post-labelling mitoses were detected in early labelled preparations of both the trisomic and normal cells, but were not shown separately because they were very few.

\section{Chromosomal sensitivity to incorporated ${ }^{3} \mathrm{H}-\mathrm{TdR}$}

The results of chromosome aberration yields in two sub-populations of the trisomic and normal cells are summarized in Table 4. There was no statistical difference between the two sub-populations either in types of aberrations or aberrant cells in both trisomic and normal cells. Therefore, the data of the two sub-populations were combined in each group and the chromosomal sensitivities to incorporated ${ }^{3} \mathrm{H}-\mathrm{TdR}$ was compared between the trisomic and normal cells. The results indicated that the chromosomes of trisomic cells were more sensitive and showed significantly higher aberration yields for both chromatid- and chromosome-type aberrations $(\mathrm{p}<0.005)$.

\section{DISCUSSION}

Recently various investigations have indicated the presence of at least two subpopulations in human PHA-stimulated lymphocyte cultures (Michalowski, 1963; Bender and Brewen, 1969; Steffen and Michalowski, 1973; Dudin et al., 1974). The 


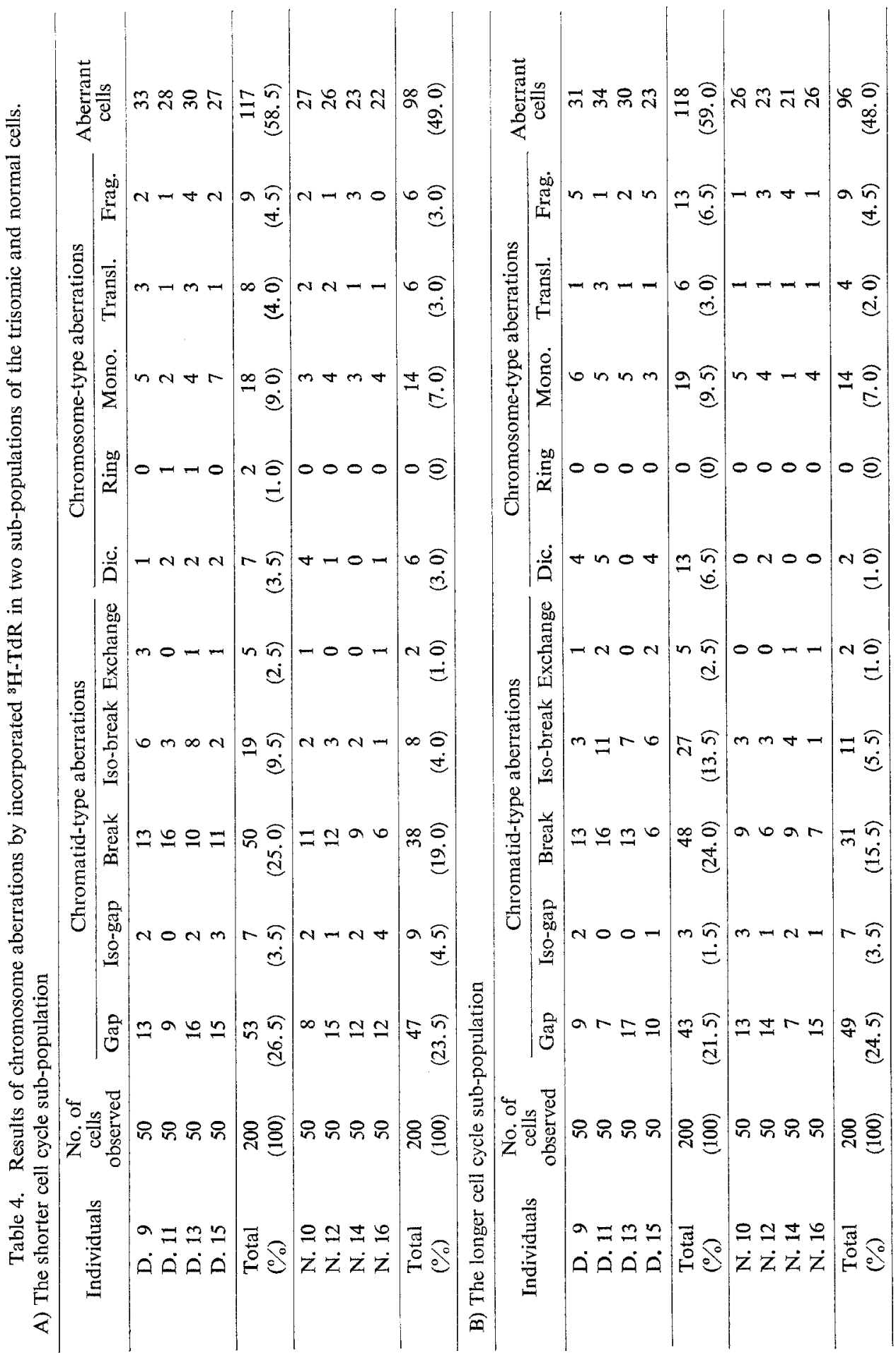


present cell cycle analyses in 72-hr lymphocyte cultures demonstrated that the two sub-populations really exist both in the trisomic cells of Down's syndrome as well as in the normal controls.

In the present experiments the MLI curves of the first post-labelling mitosis were very resembled one another in the trisomic and control cells, respectively. Therefore, the $T_{\mathrm{S}}$ and $\mathrm{T}_{\mathrm{G}_{2}+\mathrm{M}}$ were thought to be almost equal or not so different between the two sub-populations, and estimated as 8.1 and $3.9 \mathrm{hr}$ for the trisomic cells and 7.9 and $4.6 \mathrm{hr}$ for the controls, respectively. On the other hand, the $\mathrm{T}_{\mathrm{S}}$ and $\mathrm{T}_{\mathrm{G} 2+\mathrm{M}}$ measured from the 48-hr MLI curves were somewhat longer than those measured from the 72hr MLI curves, showing 10.6 and $4.8 \mathrm{hr}$ for the trisomic cells and 10.4 and $5.0 \mathrm{hr}$ for the controls. The difference in the duration between the 48- and 72-hr MLI curves might be due to the acceleration by successive divisions, in contrast to an increase of $\mathrm{T}_{\mathrm{S}}$ with increasing divisions (Younkin, 1975).

In 1974, Kukharenko et al. and Paton et al. compared the cell cycle times in human fibroblastic cultures established from normal persons and patients with trisomic conditions, including Down's syndrome. In their experiments, the results indicated that in trisomic cells the $\mathrm{G}_{2}$ phase was longer than that of the normal controls. However, the present analyses could not find out such a lengthening of $T_{\mathrm{G}_{2}+\mathrm{M}}$ for the trisomic lymphocyte cultures. Considerable difference was found for $T_{G_{1}}$ of the longer cell cycle sub-population. Consequently, the mean duration of the total cell cycle for the longer cell cycle sub-population lengthen in the trisomic cells than in the normal cells.

In the present studies, the yields of chromosome aberrations by incorporated ${ }^{3} \mathrm{H}$-TdR were compared between the two sub-populations in the trisomic and normal controls. However, no difference was found between the two sub-populations either in the trisomic or normal groups. Bender and Brewen (1969) suggested that in normal lymphocyte cultures a cell sub-population which entered earlier into mitosis after PHA-stimulation might be more sensitive concerning the induction of dicentrics and rings by ionizing radiations. Similar evidence for the production of chromosome aberrations has been indicated by Beek and Obe (1974) in their experiments treated together with ${ }^{3} \mathrm{H}-\mathrm{TdR}$ and an alkylating agent, A 139 (2,5-bis-(methoxyethoxy)-3,6-bis-(ethyleneimino)-p-benzoquinone). In the present experiments, it is not clear that either of the sub-populations enters earlier into mitosis. Furthermore, there is no confirmation whether the present two sub-populations are precisely coincide with their sub-populations or not, because the classification of sub-populations is based on the different properties.

On the other hand, a significant difference was found in the chromosome aberration yields between the trisomic and normal cells. Since the elevated level of the chromosome aberrations by irradiations was not specific to the trisomic state of chromosome No. 21 (Sasaki et al., 1970), the different chromosomal radiosensitivity in trisomic cells might be due to some altered enzymatic conditions rather than different cell cycle parameters. 
Acknowledgment The author is indebted to Professor Akira Tonomura, Department of Cytogenetics, Medical Research Institute, Tokyo Medical and Dental University, for valuable suggestions and reading manuscript.

\section{REFERENCES}

Beek, B. and Obe, G. 1974. The human leukocyte test system. II. Different sensitivities of subpopulations to a chemical mutagen. Mutat. Res. 24: 395-398.

Bender, M. A and Brewen, J. G. 1969. Factors infiuencing chromosome aberration yields in the human peripheral leukocyte system. Mutat. Res. 8: 383-399.

Dudin, G., Beek, B. and Obe, G. 1974. The human leukocyte test system. I. DNA synthesis and mitosis in PHA-stimulated 2-day cultures. Mutat. Res. 23: 279-281.

Hayakawa, M., Matsui, I., Higurashi, M. and Kobayashi, N. 1968. Hyperblastic response to dilute P.H.A. in Down's syndrome. Lancet i: 95-96.

Higurashi, M., Tamura, T. and Nakatake, T. 1973. Cytogenetic observations in cultured lymphocytes from patients with Down's syndrome and measles. Pediat. Res. 7: 582-587.

Higurashi, M., Tada, A., Miyahara, S., Hirayama, M., Hoshina, H. and Tamura, T. 1976. Chromosome damage in Down's syndrome induced by chikinpox infection. Pediat. Res. 10: 189-192.

Kukharenko, V.I., Kuliev, A. M., Grinberg, K. N. and Terskikh, V. V. 1974. Cell cycles in human diploid and aneuploid strains. Humangenetik 24: 285-296.

Matte, R., Sasaki, M. and Obara, Y. 1969. Blastic responce of lymphocytes in mosaic Down's syndrome under serial PHA dilutions. Jap. J. Human Genet. 14: 160-162.

Michalowski, A. 1963. Time course of DNA synthesis in human leukocyte cultures. Exp. Cell Res. 32: 609-612.

O'Brien, R. L., Poon, P., Kline, E. and Parker, J. W. 1971. Susceptibility of chromosomes from patients with Down's syndrome to 7,12-dimethylbenz(a)anthracene-induced aberrations in vitro. Int. J. Cancer 8: 202--210,

Okey, C. H. 1967. Chromatid aberrations resulting from ${ }^{3} \mathrm{H}$-thymidine incorporation into early and late S period in human fibroblasts. Int. J. Radiat. Biol. 13: 479-484.

Paton, G. R., Silver, M. F. and Allison, A. C. 1974. Comparison of cell cycle time in normal and trisomic cells. Humangenetik 23: 173-182.

Sasaki, M. and Obara, Y, 1969. Hypersensitivity of lymphocytes in Down's syndrome shown by mixed leukocyte culture experiments. Nature 222: 596-598.

Sasaki, M. S. and Tonomura, A. 1969. Chromosomal sensitivity in Down's syndrome. Jap. J. Human Genet, 14: 81-92.

Sasaki, M. S., Tonomura, A. and Matsubara, S. 1970. Chromosome constitution and its bearing on the chromosomal radiosensitivity in man. Mutat. Res. 10: 617-633.

Schuler, D., Fekete, G. und Dobos, M. 1972. Mit einem alkylierenden Agens (Zitostop) in vitro induzierbare Mutationen bie Malignomen und bie Syndromen, die zur Malignität Disponieren. Humangenetik 16: 329-336.

Segal, D. J. and McCoy, E. E. 1973. Studies on Down's syndrome in tissue culture. I. Growth rate and protein contents of fibroblast cultures. J. Cell Physiol. 83: 85-90.

Steffen, J. and Michalowski, A. 1973. Heterogeneous chromosomal radiosensitivity of phytohemagglutinin-stimulated human blood lymphocytes in culture. Mutat. Res. 17: 367-376.

Younkin, L. H. 1975. In vitro response of lymphocytes to phytohemagglutinin (PHA) as studied with antiserum to PHA. II. Cell cycle analysis. Exp. Cell Res. 90: 374-380. 